\title{
Current distribution of Pilularia globulifera L. in Poland - changes of geographical range and habitat preferences
}

\author{
Ewa Szczęśniak', Stanisław Rosadziński², Krzysztof Spałek³, Mariusz Szymanowski ${ }^{4}$, Agnieszka Kreitschitz ${ }^{5}$ Jerzy \\ $\mathrm{Kruk}^{6}$, Michał Śliwiński ${ }^{1 *}$, Ryszard Kamiński ${ }^{7}$ \\ ${ }^{1}$ Department of Biodiversity and Plant Cover Protection, University of Wrocław, Kanonia 6/8, 50-328 Wrocław, Poland \\ ${ }^{2}$ Department of Plant Ecology and Environmental Protection, Adam Mickiewicz University, Umultowska 89, 61-614 Poznań, Poland \\ ${ }^{3}$ Department of Biosystematics, University of Opole, Oleska 22, 45-052 Opole, Poland \\ ${ }^{4}$ Institute of Geography and Regional Development, University of Wrocław, PI. Uniwersytecki 1, 50-137 Wrocław, Poland \\ ${ }^{5}$ Institute of Experimental Biology, University of Wrocław, Kanonia 6/8, 50-328 Wrocław, Poland \\ ${ }^{6}$ Department of Plant Physiology and Biochemistry, Jagiellonian University, Gronostajowa 7, 30-387 Cracow, Poland \\ ${ }^{7}$ Botanical Garden, University of Wrocław, Sienkiewicza 23, 50-335 Wrocław, Poland
}

\section{Abstract}

Pilularia globulifera is a subatlantic European fern threatened with extinction. In Poland, it reaches the eastern border of its continuous range. Up to the end of the 20th century, it was observed here in 21 stands; only 2 of them existed by the second half of the century, so the species was categorized as critically endangered. Five new locations have been found in western and northwestern Poland during the last 10 years. Abundant and permanent populations grow in 3 locations, while 2 stands were ephemeral. All the current stands are situated in anthropogenic habitats with spontaneous vegetation, in oligotrophic to eutrophic waters. One of the new localities is about $280 \mathrm{~km}$ distant from the eastern range of the limit known previously. Pilularia forms its own plant community Pilularietum globuliferae, enters plots of Ranunculo-Juncetum bulbosi and occurs in mesotrophic to eutrophic rushes of Eleocharis palustris, Phragmites australis, Typha angustifolia and Equisetum fluviatile. Specimens are vigorous and regularly produce sporocarps.

Keywords: water ferns, Pilularia globulifera, apophyte, climate warming, Poland

\section{Introduction}

The genus Pilularia (Marsiliaceae) is represented by 5 to 6 species distributed in North and South America, Europe, the Pacific Islands, New Zealand, Australia and Africa [1-3]. In Europe, two species occur: Pilularia minuta Dureu ex A. Braun, limited to the western Mediterranean region, and a widely distributed Pilularia globulifera L. [4]. Pilularia globulifera is a subatlantic species, originally recorded throughout much of Western Europe's lowlands, from southern Scandinavia to the Iberian Peninsula [5]. In Central Europe, it reaches the eastern boundary of its continuous range and has been reported in Germany [6], the southern part of Czech Republic [7] and western Poland [8]. Some isolated and easternmost stands

*Corresponding author. Email: michal.sliwinski@o2.pl

Handling Editor: Krzysztof Spalik

This is an Open Access digital version of the article distributed under the terms of the Creative Commons Attribution 3.0 License (creativecommons.org/licenses/by/3.0/), which permits redistribution, commercial and non-commercial, provided that the article is properly cited. were recorded on the bank of Kugurluj Lake in the Danube River valley near its delta, as probably accidentally introduced [9], and in the Karelian Isthmus [10]. Generally, in Europe, $P$. globulifera is classified as near threatened (NT) due to lack of information sufficient to assign it to a given threat class - it most likely should be assigned as a vulnerable species [11]. In Central Europe this taxon is classified as endangered (EN) [12]. It is critically endangered in Switzerland [13], Czech Republic [7] and Poland [8], endangered in Germany [14] and Norway [15], vulnerable in Finland [16] and Sweden [17] and very rare in the Netherlands [18].

Pillwort $P$. globulifera is a heterosporous coastal and submerged aquatic fern with numerous cylindrical leaves, propagating by spores or by fragmentation of rhizomes. Usually, it occupies bare gravel or silt at the banks of lakes, ponds, temporary pools and slow flowing rivers, but also survives periods of complete immersion. It is strongly associated with places of fluctuating water levels, which suppress competition from higher plants. The fern prefers neutral to acidic substrates, and permanently damp habitats in summer, warmed rapidly by the sunshine. The chromosome number for the species is $2 n=26[4,11,19-22]$.

In Poland, the species was recorded in the western and northwestern regions, where it occurred in peat bogs, natural and anthropogenic ponds, as well as wet meadows. Up to 1940, 
it was observed in ca. 20 locations [23-30]. The number of locations suddenly declined and at the end of the 20th century, with only two stands existing in Janiszowickie Lake near Lubsko and in a fishpond near the village of Niwica, both in western Poland. In Janiszowickie Lake, $P$. globulifera was recorded in 1982 and 1983 , later it disappeared, probably due to increased water level [8]. During regular controls, it has not been confirmed until now. The current high eutrophication of the lake promotes the growth of rushes; even if pillwort survived a period of deep immersion, it might have been overgrown and eliminated by more competitive species. The second population thrived in the years 1988-2001 [8,31]; however, since 2007, it has not been confirmed. The fishpond in Niwica is intensively exploited; the level of eutrophicated water is permanently high.

Pilularia globulifera is classified as a critically endangered species in the "Polish red book" $[8,32]$ and the "Red list of vascular plants" [33,34]. In the first decade of the 21 st century we found 5 new locations of this extraordinary fern, and the discovery motivated us to undertake detailed research on the current distribution and ecology of the pillwort in Poland.

\section{Material and methods}

The distribution of $P$. globulifera was studied in 2007-2011. Historical information about stands of this species in Poland was verified in field research. In addition, potential locations indicated during a detailed analysis of orthophotomaps on Google Maps and Geoportal (http://maps.geoportal.gov.pl/ webclient/), were also examined.

To compare current thermal conditions of stands located between the historic range and the new eastern location, analyses of mean annual and coldest monthly (January) air temperature for the decade 1996-2005 were undertaken. Moreover, the same analyses were made for the decade 1951-1960, to determinate changes of temperature factor caused by climate warming. Maps of mean annual and January air temperature for the decade 1996-2005 were prepared based on data from 250 meteorological stations from Poland and the immediate vicinity abroad. Air temperature averages were obtained from Institute of Meteorology and Water Management and from the freely available databases of the National Climatic Data Center: GHCN-M [35] and GSOD [36]. Data from Germany were obtained from the Deutscher Wetterdienst website [37]. Spatial interpolation was performed using geographically weighted regression-kriging (GWRK), the method which is a two-part modelling procedure consisting of deterministic (local regression) and stochastic (ordinary kriging) components [38]. Deterministic models for annual and January means were specified using step-wise regression and a set of auxiliary environmental variables such as: altitude, longitude, latitude and distance from the sea among others. Regression residuals were spatialized by ordinary kriging technique [39]. Because the access to climatological data from the decade 1951-1960 was limited to only less than 60 stations [35], air temperature fields for that period were estimated using simple linear regression formulas with air temperatures from 1996-2005 as the independent variables. Correlation coefficients between datasets from two decades for annual and January means reached 0.98 and 0.80 respectively. The potential range of the species due to thermal conditions was estimated for each decade separately by combining (logical conjunction) annual and January raster layers, under the assumption that the spatial range is limited by annual mean temperature of less than $8.0^{\circ} \mathrm{C}$ and a January mean temperature of less than $2.5^{\circ} \mathrm{C}$. We estimated values of temperatures determining stability of $P$. globulifera populations in Poland according to temperatures noted in eastern boundary of continuous range of the fern. Statistical and spatial analyses were performed using Statistica 9.1 and ArcGIS 9.3 (with Spatial Analyst and Geostatistical Analyst extensions) software.

Detailed research of existing populations was done on the production of sporocarps, viability of spores, chromosome number and relationship to plant communities. The viability of spores was tested at a stand by, controlling for spontaneous presence of the young fern, and in a laboratory, in water, at room temperature. The number of produced sporocarps was observed in three permanent populations, in Krzyżowa and Brożek in November 2009 and in Poręba Wielka in October 2011 , on five $50 \times 50 \mathrm{~cm}$ plots for each stand.

To count the chromosome number in plants originating from the three permanent stands, root tips were collected from fast growing rhizomes. They were pretreated with 0.004 $\mathrm{M}$ oxychinoline for 4 hours at room temperature in the dark and then fixed for 24 hours in a mixture of absolute ethanol and glacial acetic acid $(3: 1, \mathrm{v} / \mathrm{v})$ at a temperature $5.0^{\circ} \mathrm{C}$. The meristems were stained using Feulgen method [40] and then squashed and mounted in a drop of $45 \%$ acetic acid.

Relevés were recorded using the Braun-Blanquet scale [41] and stored in a TURBOVEG database [42]. A numerical classification of the plots was made by TWINSPAN software package integrated with JUICE programme [43]. The analysis was based on presence/absence of information on the species. Ordination analysis was done with a CANOCO software [44], data was elaborated using a detrended correspondence analysis (DCA) and canonical correlation analysis (CCA). Plant communities and the diagnostic value of vascular plants were identified according to Matuszkiewicz [45], the diagnostic value of mosses according to Dierßen [46]. The nomenclature of vascular plants is given according to Mirek et al. [47].

A distribution map was generated using GNOMON software in $10 \times 10 \mathrm{~km}$ squares of the ATPOL grid [48].

\section{Results}

\section{Localities}

Pilularia globulifera was observed in Poland on 25-27 locations in the 22 ATPOL squares (Fig. 1). The majority of stands (73\%) were recorded before 1945 and not confirmed later; the abbreviation l.n.c. denotes a locality checked by the authors and not confirmed after 2001.

AD 55: the eastern bank of Janiszowickie Lake [29], observed only in 1982/ 83 [49], later not confirmed [8,31,32,50], M. Pawlus 1982.09.07 (KRA), l.n.c.; 65: Lubsko, not confirmed [8,32,50], leg. Struve 1877.06.16 (POZ), l.n.c.; NE of Lubsko, a new water reservoir, Rosadziński 2009, not confirmed since 2010; 68: Pierzwin near Kożuchów [27], not confirmed [8,32,50], l.n.c.; 73: two abandoned gravel pits in Brożek near Zasieki, Rosadziński, Szczęśniak and Śliwiński 2007-2011; 83: a valley stream near spruce, pine and fir trees between Gniewoszyce, Chwaliszczewice and Żarki Wielkie [30], not confirmed [8,32,50], l.n.c.; 84: Niwica near Mużaków/Muskau [23,27,30], not confirmed [50]; a fishpond near a road to Łęknica [31], confirmed [8,32,51] (the same stand?), J. Chmiel 1990.09.08 (POZ), not confirmed since 2007; 86: Żary, Struve 1872 (POZ), l.n.c. 


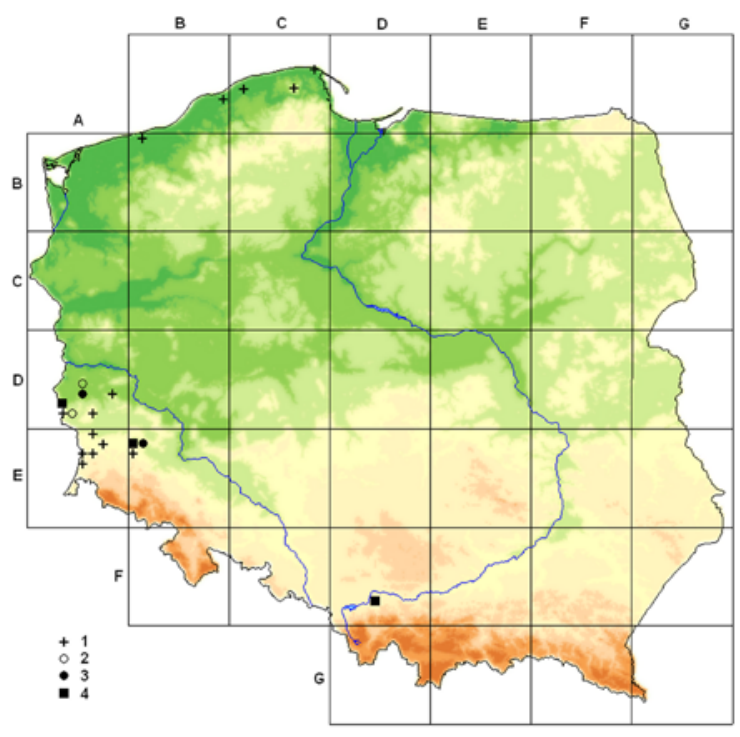

Fig. 1 Distribution of Pilularia globulifera L. in Poland. 1 - stands recorded before 1945; 2 - stands recorded in 1945-2001; 3 - stands recorded after 2001, ephemeral; 4 - stands recorded after 2005, currently exist.

AE 06: Syczków pond near Ruszów [hand-made note in a copy of Kryptogamenflora von Schlesien by Ferdinand Cohn (1876) deposited in the library of the University of Opole], 1.n.c.; 17: a heath near Osiecznica $[23,27]$, not confirmed $[8,32,50]$, l.n.c.; 25: a peat bog near Dłużyna [27], not confirmed [8,32,50], 1.n.c.; 26: a peat bog near Węgliniec $[23,27]$, not confirmed [8,32,50], l.n.c.; 35: between Jędrzychowice and Żarki Średnie $[23,27]$, not confirmed $[8,32,50]$, l.n.c.; near Zgorzelec, leg. Struve 1852 (POZ), l.n.c.

BA 69: a heath in Bydlino near Słupsk [24-26], not confirmed $[8,32,50]$, l.n.c.; near Słupsk (the same stand?), N.N., 1869 (POZ), l.n.c.

BB 60: a ditch in a peat bog in Stramnica near Kołobrzeg $[25,26,52]$, not confirmed $[8,32,50]$, l.n.c.

BE 10: two fishponds in Krzyżowa near Bolesławiec [53], Szczęśniak, Śliwiński 2007-2011; 11: a fishpond in Rokitki [54], not confirmed since 2009; 20: between Osła and Wilczy Las [23,27], not confirmed [8,32,50], l.n.c.; 29: dry ponds S of Krzywa near Chojnów [23,27], not confirmed [8,32,50], l.n.c.

CA 38: Bielawskie Błoto, $S$ of Ostrowo [28], not confirmed [8,32,50], l.n.c.; 51: Siecie near Słupsk [25,26], not confirmed [8,32,50], l.n.c.; 56: Salińskie (Salino) Lake near Lębork [24-26,28], not confirmed [8,32,50], l.n.c.

DF 74: a fishpond in Poręba Wielka near Oświęcim [55], Kruk, Szczęśniak and Śliwiński 2009-2011.

\section{Characteristics of the stands}

Pilularia globulifera has been found in five locations within the last five years. All current stands are associated with the spontaneous vegetation of anthropogenic habitats; three occur in fishponds, one in a new recreational pond and one in abandoned gravel pits, partially swamped and immersed. The species was not observed in natural habitats and should be classified as an apophyte in the present Polish flora. Four stands are located within the previous geographical range of P. globulifera in Europe; one is ca. $280 \mathrm{~km}$ beyond its eastern boundary (Fig. 1). Habitat characteristics of those five locations are presented below. (i) Brożek near Zasieki: two adjacent shallow water reservoirs in old gravel pits situated in the flooding area of the Nysa Łużycka River. The gravel pits were probably abandoned at the end of the 1990s. The succession of forest communities is limited here by the changing level of water and flooding during springtime. Pilularia occurs on sandy and oligotrophic initial soils and occupies an area of 60 to $300 \mathrm{~m}^{2}$, depending on the water level. The fern develops submersed and emerged forms at the stand in its own community and also occurs in the rushes of Phragmites australis.

(ii) Lubsko: ephemeral occurrence on an open sandy bank of a new water reservoir. Pilularia was observed on an area of ca. $2 \mathrm{~m}^{2}$. The reservoir is used by the local community as a recreational pond, thus the pillwort habitats are under extreme human pressure. The species was observed in 2009 and not confirmed later. Possibly, the fern did not survive the winter and was too young or emerged too late to produce sporocarps.

(iii) Krzyżowa: two anthropogenic fishponds in a forest, which have been dug in the wet valley of a small stream and are supplied by the stream as well as by oligotrophic water coming from a drainage system. A detailed description of the stand was given by Szczęśniak and Szlachetka [53]. Pilularia occurs on open sandy banks and a flat bed and shallow water covering an area of 1 (in 2011) to $1500 \mathrm{~m}^{2}$ (in 2007) in the northern pond and $0.5-2 \mathrm{~m}^{2}$ in the southern pond; the area depends on the time of clearing of the ponds. The fern developed submersed and emerged shoots forming its own community and entering into Phragmitetum australis rushes.

(iv) Rokitki: probably ephemeral occurrence in an anthropogenic pond in the western complex of the fishponds. In summer 2008, a few juvenile plants were observed on the sandy bottom of a transiently drying pond [54]. Before they grew enough to produce sporocarps, the pond was filled again and Pilularia remained under water. The extinction or survival of the pillwort has not been determined.

(v) Poręba Wielka near Oświęcim: an abandoned anthropogenic fishpond, temporarily dried out and partially covered by rushes; part of the large complex of fishponds between Oświęcim and Zator. A detailed description of the stand was given by Kruk and Szymańska [55]. Population developed in clay; it is the most eutrophic habitat of Pilularia in Poland. The fern forms dense plots covering over 2000 to $3000 \mathrm{~m}^{2}$ at the bottom in the southern part and some small plots dispersed in the northern part. The population is vigorous. Pilularia forms its own community; moreover, it occurs in rushes of Typha angustifolia, Eleocharis palustris and Equisetum fluviatile. The locality is controlled every year and over the years 2009-2011, the population area and condition did not change significantly.

Analyses of mean annual and January air temperatures revealed a high similarity of thermal conditions noted in the decade 1951-1960 within the Polish part of P. globulifera continuous geographical range with the temperatures noted in the decade 1996-2005 in the surroundings of the new eastern stand. The means for Poręba Wielka in the decades 1951-1960 were $7.9^{\circ} \mathrm{C}$ and $-4.0^{\circ} \mathrm{C}$; they increased significantly in the decade $1996-2005$ to $8.3^{\circ} \mathrm{C}$ and $-2.2^{\circ} \mathrm{C}$, respectively.

\section{Biology and ecology}

PROPAGATION. The species is able to propagate vegetatively by fragmentation of branching rhizomes and generatively by formation of sporocarps and the sexual process. Sporulation was observed in Brożek, Krzywa and Poręba Wielka. 
Sporocarps occurred on 10 to $30 \%$ of the entire population area and matured from August to November. On five plots tested in every stabile population, we noted 50 sporocarps on average in the oligotrophic habitat developed in the flat pond bottom in Krzyżowa, whereas in Brożek, where the habitat is also oligotrophic, but the bottom relief is more diversified, 70 sporocarps occurred on average. The highest number of sporocarps, 112 on average, was observed in Poręba Wielka in the eutrophic habitat with irregular surface of the fishpond bed, where ferns mature earlier.

VIABILITY OF SPORES. The majority of spores were viable, gametophyte development started in about $70 \%$ of macrospores. The green parts of the female prothalli protruding from spores were discoid; some of them developed short structures that may be identified as rudimentary rhizoids. Male prothalli were hidden inside spores; male gametes were released faster in warm water.

CHROMOSOME NUMBER. In all populations it was found to be $2 n=26$.

MORPHOLOGY. Depending on water depth, Pilularia develops two morphological forms: terrestrial and aquatic. Plants growing on an emerged substratum form short and dense tufts, with erect and succulent leaves up to $10(-12) \mathrm{cm}$ long. The smallest mature specimen of terrestrial form was noted in Poręba Wielka and reached $1.2 \mathrm{~cm}$. Ferns growing in water have delicate and slender leaves, up to $50 \mathrm{~cm}$ long. Newly immersed areas are colonized by long rhizomes with internodes up to $14 \mathrm{~cm}$ long; secondary branches are short with internodes up to $5 \mathrm{~cm}$, often only a few millimeters long. Long colonizing rhizomes develop in water, ferns growing on emerged stands form mainly shoots with short internodes.

OCCURRENCE IN PLANT COMMUNITIES. The species occurs in two types of plant communities: in pioneer vegetation of the class Litorelletea uniflorae Br.-Bl. Et R. Tx. 1943 developed on newly emerged banks and bottoms, and in two-level vegetation consisting of rushes and small herbs associated with areas of low water level or prolonged emersion.

Pioneer vegetation with $P$. globulifera belonged to two plant communities. The fern was observed in the association Ranunculo-Juncetum bulbosi (Nordh. 1921) Oberd. 1957 of the alliance Lobelion (van den Bergen 1944) R. Tx. et Dierss. ap Dierss. 1972 developed on the wet or immersed banks of ponds in Rokitki and Krzyżowa, under water up to $10 \mathrm{~cm}$ deep. Phytocoenoses were moderately rich and consisted of 10-15 taxa. Participation of $P$. globulifera was rather small, it covered about $10 \%$ of the relevé area, other species of the Litorelletea uiflorae class, i.e. Juncus bulbosus or Hydrocotyle vulgaris were dominated (Tab. 1, relevés 1-3).

Under optimal habitat conditions, the species formed the subatlantic plant community Pilularietum globuliferae R. Tx. 1955 ex Müll. et Görs 1960 of the alliance Hydrocotylo-Baldenion R. Tx. Et. Deirss. ap. Dierss. 1972. Plant cover of the richest plots comprised of 14-22 plant species. These areas emerged in late summer and development of emersed phytocoenoses lasted about 3 months. Pilularia formed mats covering $50-80 \%$ of the area. Permanent elements of the patches were character species of the classes Litorelletea uniflorae (e.g., Ranunculus flammula, Juncus bulbosus), Isoëto-Nanojuncetea Br.-Bl. et R. Tx. 1943 (e.g., Elatine hexandra, Peplis portula, Gnaphalium uliginosum), Scheuchcerio-Caricetea nigrae (Nordh. 1937) R. Tx. 1937 (e.g., Juncus articulatus), Bidentetea tripartiti R. Tx., Lohm et Prsg 1950 (e.g., Bidens frondosa, B. radiata, Polygonum hydropiper) and Phragmitetea R. Tx. et Prsg 1942 (e.g., Alisma plantagoaquatica, Eleocharis palustris, Phragmites australis), but their contribution was rather small (Tab. 1, relevés 4-12). Moreover, species of the Phragmitetea class were almost always undersized
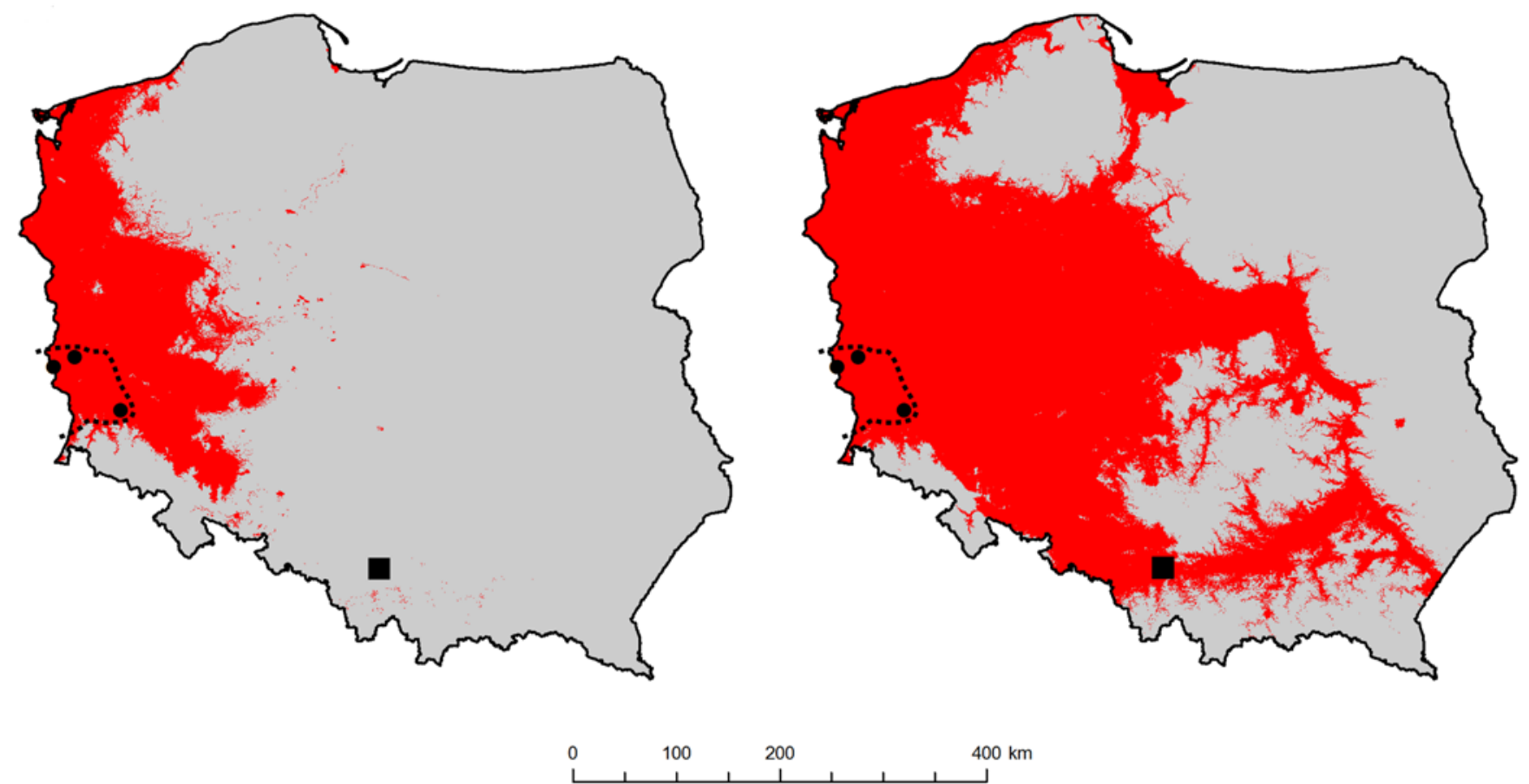

Fig. 2 The area of temperatures sufficient for Pilularia globulifera to perform complete vegetation cycle in decades 1951-1960 (left) and 1996-2005 (right). Black circle - stand noted in last 10 years within continuous geographical range; black square - stand noted within last 10 years beyond continuous geographical range; dotted line - border of continuous geographical range. 
Tab. 1 Pioneer plant communities of the class Litorelletea uniflorae with Pilularia globulifera.

\begin{tabular}{|c|c|c|c|c|c|c|c|c|c|c|c|c|c|c|c|c|c|c|c|c|c|c|}
\hline No. of relevé & 1 & 2 & 3 & 4 & 5 & 6 & 7 & 8 & 9 & 10 & 11 & 12 & 13 & 14 & 15 & 16 & 17 & 18 & 19 & 20 & 21 & \\
\hline Month & 06 & 08 & 08 & 09 & 09 & 09 & 07 & 11 & 08 & 08 & 08 & 11 & 10 & 08 & 09 & 09 & 07 & 10 & 10 & 08 & 10 & \\
\hline Year & 08 & 08 & 09 & 10 & 82 & 10 & 09 & 09 & 10 & 10 & 10 & 09 & 11 & 10 & 82 & 10 & 08 & 11 & 11 & 08 & 11 & \\
\hline Area in $\mathbf{m}^{2}$ & 50 & 6 & 6 & 6 & 10 & 10 & 2 & 0,5 & 20 & 20 & 15 & 1 & 18 & 12 & 30 & 8 & 9 & 20 & 10 & 10 & 25 & \\
\hline Cover of herb layer (\%) & 70 & 80 & 70 & 95 & 95 & 100 & 90 & 70 & 95 & 80 & 80 & 70 & 90 & 90 & 90 & 80 & 90 & 95 & 95 & 80 & 30 & \\
\hline Cover of moss layer (\%) & . & . & . & + & . & . & + & . & . & . & . & + & . & . & . & . & . & . & . & & . & $\widehat{\breve{a}}$ \\
\hline Location & $\mathrm{R}$ & $\mathrm{K}$ & $\mathrm{K}$ & $\mathrm{B}$ & $\mathrm{J}$ & B & $\mathrm{B}$ & $\mathrm{L}$ & $\mathrm{P}$ & $\mathrm{P}$ & $\mathrm{P}$ & $\mathrm{L}$ & $\mathrm{P}$ & $\mathrm{P}$ & $\mathrm{J}$ & $\mathrm{B}$ & B & $\mathrm{P}$ & $\mathrm{P}$ & $\mathrm{K}$ & $\mathrm{P}$ & $\ddot{n}$ \\
\hline
\end{tabular}

\section{Cl. Litorelletea uniflorae}

Pilularia globulifera

Ranunculus flammula

Juncus bulbosus

Hydrocotyle vulgaris

Carex viridula

Eleocharis acicularis

Veronica scutellata

Eleocharis mamillata

\section{Cl. Isoeto-Nanojuncetea}

Peplis portula

Elatine hexandra

Gnaphalium uliginosum

Plantago intermedia

Bryum pallens d

Juncus bufonius

$\begin{array}{lllllllllllllllllllllll}1 & 1 & 1 & 5 & 4 & 4 & 4 & 4 & 5 & 4 & 3 & 3 & 5 & 5 & 5 & 5 & 5 & 5 & 5 & 5 & 2 & \text { V } \\ 1 & 1 & + & + & 2 & + & . & . & + & + & + & . & + & + & + & . & . & . & . & . & + & \text { III } \\ . & 2 & 2 & + & 2 & 2 & 1 & . & . & . & . & . & . & . & + & \text { r } & . & . & . & . & . & \text { II } \\ 3 & 3 & 3 & 2 & 1 & . & . & . & . & . & . & . & . & . & . & . & . & . & . & . & . & \text { II } \\ 2 & + & \text { r } & + & 1 & . & . & + & . & . & . & 3 & . & . & . & . & . & . & . & . & . & \text { II } \\ 2 & . & . & . & . & . & . & + & . & . & . & . & 1 & . & . & . & . & . & . & . & + & \text { I } \\ 1 & . & . & . & . & + & . & . & . & . & . & . & . & . & . & . & . & . & . & . & . & \text { I } \\ . & . & . & + & . & . & + & . & . & . & . & . & . & . & . & . & . & . & . & . & . & \text { I }\end{array}$

Sporadic: Fossombronia incurva d 7(+); Juncus capitatus 17(r); Trichodon cylindricus d 6(+), 7(+).

\section{Cl. Scheuchcerio-Caricetea nigrae}

Juncus articulatus

Carex lasiocarpa

Sporadic: Agrostis canina 5(+), 9(r); Drosera intermedia 16(+); Lycopodiella inundata 16(+); Riccardia chamedryfolia d 4(+).

\section{Cl. Phragmitetea}

Alisma plantago-aquatica

Eleocharis palustris

Phragmites australis

Phalaris arundinacea

Typha angustifolia

Glyceria fluitans

Sporadic: Carex elata 4(+); C. pseudocyperus 4(r), 5(1); Cicuta virosa 5(+), 15(+); Galium palustre 5(+), 15(+); Glyceria maxima 9(+), 11(r); Rorippa

amphibia $15(+)$.

\section{Cl. Bidentetea tripartiti}

Bidens frondosa

Bidens radiata

Polygonum hydropiper

Rorippa palustris

Alopecurus aequalis

Sporadic: Bidens cernua 5(+); Polygonum lapatifolium 5(+); P. mite 14(+); Ranunculus sceleratus 8(r), 12(r).

\section{Cl. Molinio-Arrhenatheretea}

Lysimachia vulgaris

Epilobium palustre

Juncus effusus

Myosotis palustris

Juncus conglomeratus

Sporadic: Agrostis stolonifera 7(+), 15(+); Leontodon autumnalis 5(+); Lythrum salicaria 8(r). 
Tab. 1 (continued)

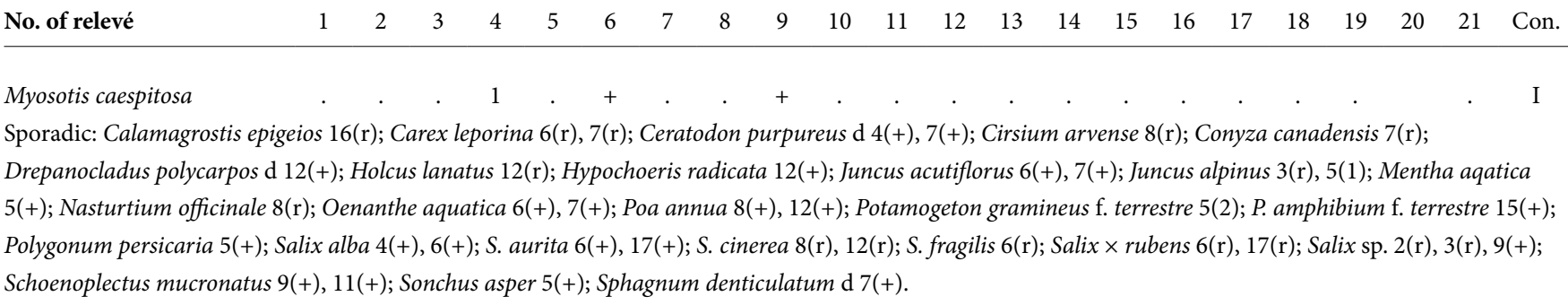

Location: B - Brożek; J - Janiszowice [49]; K - Krzyżowa; L - Lubsko; P - Poręba Wielka; R - Rokitki [54].

and sterile. The poorest plots consisting of 3-12 species emerged in late autumn and development of emersed vegetation lasted about one month. Pilularia globulifera covered 80 to $100 \%$ of all patches, sometimes forming almost one species aggregation. The other recorded plant species, including therophytes of the classes Litorelletea uniflorae, Isoëto-Nanojuncetea and Bidentetea tripartiti, as well as single plants of perennial rushes of the Phragmitetea class, were nearly always juvenile or sterile.

In the second type of vegetation, the pillwort occurred in two-level communities formed by small species of the classes Litorelletea uniflorae (e.g., Juncus bulbosus, Ranunculus flammula) and Isoëto-Nanojuncetea (e.g., Elatine hexandra, Peplis portula, Gnaphalium uliginosum), and well-developed mature and flowering perennial plants of the Phragmitetea class (e.g., Alisma plantago-aquatica, Eleocharis palustris, Phragmites australis, Typha angustifolia; Tab. 2). Pilularia can enter the rushes after an increase in water level as in Krzyżowa, where the ponds are still used as fishponds, or rushes enter the habitats of Pilularietum globuliferae, when the area is abandoned and devoid of regular periods of emersion and immersion. In such habitats, pillwort was recorded in the communities: Phragmitetum australis (Gams 1927) Schmale 1939, Typhetum angustifoliae (Allorge 1922) Soó 1927, Eleocharitetum palustris Šennikov 1919 and Equisetetum fluviatilis Steffen 1931, where it occurred among the rushes and formed the second level of the community structure. It covered 5 to $90 \%$ of the plot with regard to the phase of rush succession.

The two main groups of relevés distinguished by TWINSPAN were the plots of Typhetum angustifoliae and patches of all other communities developed in all locations of $P$. globulifera. This division was accorded to species richness coincident with surrounding vegetation and the time of succession in area of water reservoirs, not to richness of habitat nor to the form of management. In the results of DCA and CCA analyses, the most important was also the gradient of species richness, the importance of other vectors was similar and small.

\section{Discussion}

Pilularia globulifera is a narrowly specialized coastal fern, adapted to changing habitat conditions; it can survive periods of complete immersion, is able to occur in water up to about a meter in depth, and after disappearance during years of exceptional drought, sporocarps may remain dormant for many years and start to grow under favorable conditions [21]; however, the long period of dormancy is contentious [56]. Throughout the entire range the fern is threatened with extinction. The main threats to the species are the stabilization of water levels and the drainage of temporary wetlands [11].

Natural ecological amplitude of $P$. globulifera is rather narrow and the species is associated with oligo- and mesotrophic habitats; occasionally, it was observed in eutrophic stands. A significant factor limiting the presence of the fern is the influence of modern agriculture, particularly acidification and eutrophication as a consequence of ammonium deposition and accumulation [57]. According to Landsdown [11], even a lowlevel eutrophication may pose a threat as it enables colonization of an otherwise unsuitable habitat by more competitive plants. In contrast, anthropogenic habitats colonized by Pilularia are more fertile, up to slightly eutrophic [58]. Opposite points of its ecological scale are the oligotrophic postglacial lakes in Finland, where Pilularia occurred with Isoëtes echinospora, I. lacustris, Lobelia dortmanna [59], and an eutrophic habitat observed in Germany, where the species entered flooded fields with Zea mays and grew together with Echinochloa crus-galli and Plantago major [60]. Generally, the pillwort is a weak competitor and grows mainly in habitats that are largely competition free. When competitors are eliminated, the pillwort occurs in habitats of all type of fertility.

Pilularia globulifera is a subatlantic species, which penetrates the central part of Europe and reaches there its eastern boundary of continuous geographical range. Along the eastern periphery, its populations are rare, number of stands and their quantity fluctuate irregularly and distribution of marginal populations depends mainly on winter temperatures. Nowadays, a process of rebuilding of peripheral populations seems to be observed. In Czech Republic, the species has been considered as extinct since the 1930s, but a new locality was discovered in 2007 [7]. In Poland, the number of sites recorded in last ten years is the highest since 1945 .

It is difficult to predict how narrowly specialized plant species will respond to climate change. Global warming in connection with human activity results in ground water decrease, which in turn causes the demise of peat bog and wet meadow habitats of Pilularia in the western lowlands of Poland [53]. The same factors increase the number of possible locations in anthropogenic ponds. Banks of abandoned anthropogenic ponds are flooded by freshwater in springtime and dry out during summer and autumn. Immersion stops the development of competitive species and pillwort can continually pioneer new bare sites. In ponds still used, banks and beds are permanently immersed and only periodically the entire area emerges due to the fish-breeding cycle. However, water deficit related to summer droughts resulted in a new function of selected ponds in fish-breeding complexes: they became water reservoirs emptying in summer. 
Tab. 2 Two-level plant communities of Pilularia globulifera and rushes.

\begin{tabular}{|c|c|c|c|c|c|c|c|c|c|c|c|c|c|c|c|c|c|c|c|c|c|}
\hline No. of relevé & 1 & 2 & 3 & 4 & 5 & 6 & 7 & 8 & 9 & 10 & 11 & 12 & 13 & 14 & 15 & 16 & 17 & 18 & 19 & 20 & \\
\hline Month & 09 & 09 & 09 & 09 & 09 & 09 & 09 & 08 & 10 & 08 & 10 & 08 & 08 & 10 & 10 & 08 & 08 & 10 & 10 & 10 & \\
\hline Year & 82 & 10 & 82 & 10 & 82 & 09 & 09 & 08 & 11 & 10 & 11 & 10 & 10 & 11 & 11 & 10 & 10 & 11 & 11 & 11 & \\
\hline Area in $\mathbf{m}^{2}$ & 20 & 15 & 8 & 15 & 8 & 8 & 10 & 6 & 20 & 30 & 20 & 20 & 15 & 20 & 20 & 15 & 20 & 20 & 20 & 15 & \\
\hline Cover of herb layer (\%) & 100 & 100 & 95 & 95 & 100 & 90 & 50 & 40 & 70 & 100 & 70 & 100 & 90 & 100 & 50 & 50 & 70 & 80 & 100 & 60 & \\
\hline Cover of moss layer (\%) & . & $\cdot$ & . & . & + & . & . & . & 15 & 10 & . & + & . & . & . & . & . & . & . & & 8 \\
\hline Location & $\mathrm{J}$ & B & $\mathrm{J}$ & B & $\mathrm{J}$ & $\mathrm{K}$ & $\mathrm{K}$ & $\mathrm{K}$ & $\mathrm{P}$ & $\mathrm{P}$ & $\mathrm{P}$ & $\mathrm{P}$ & $\mathrm{P}$ & $\mathrm{P}$ & $\mathrm{P}$ & $\mathrm{P}$ & $\mathrm{P}$ & $\mathrm{P}$ & $\mathrm{P}$ & $\mathrm{P}$ & \\
\hline No. of species & 15 & 15 & 9 & 16 & 17 & 14 & 12 & 11 & 25 & 23 & 8 & 15 & 14 & 17 & 17 & 16 & 15 & 15 & 8 & 9 & ن \\
\hline
\end{tabular}

\section{Cl. Litorelletea uniflorae}

Pilularia globulifera

Juncus bulbosus

Ranunculus flammula

Hydrocotyle vulgaris

Eleocharis acicularis

Sporadic: Carex viridula 6(+), 7(r); Eleocharis mamillata 11(+).

\section{Cl. Isoeto-Nanojuncetea}

Elatine hexandra

Peplis portula

Gnaphalium uliginosum

Sporadic: Limosella aquatica 14(+), 19(+); Plantago intermedia 9(+).

\section{Cl. Scheuchcerio-Caricetea nigrae}

Juncus articulatus

Agrostis canina

Sporadic: Bryum pseudotriquetrum d 5(+); Carex canescens 4(+).

\section{Cl. Phragmitetea}

Phragmites australis

Typha angustifolia

Eleocharis palustris

Equisetum fluviatile

Alisma plantago-aquatica

Cicuta virosa

Galium palustre

Peucedanum palustre

Glyceria fluitans

Sporadic: Alisma gramineum 14(r), 18(+); Carex pseudocyperus 1(+), 5(+); Lysimachia thyrsiflora 5(+); Mentha aqatica 5(+); Phalaris arundinacea 10(+),

16(r); Rorippa amphibia 14(r); Schoenoplectus lacustris 2(+); Scutelaria galericulata 9(+), 10(+); Sium latifolium 1(+), 5(+); Typha latifolia 10(+).

\section{Cl. Bidentetea tripartiti}

Bidens frondosa

Bidens radiata

Polygonum hydropiper

Bidens cernua

Rorippa palustris

Polygonum mite

Alopecurus aequalis

\section{Cl. Molinio-Arrhenatheretea}

Juncus effusus

Lysimachia vulgaris

Lythrum salicaria

Myosotis palustris

Agrostis stolonifera

Epilobium palustre

Sporadic: Cirsium palustre 9(+); Galium uliginosum 9(+); Juncus conglomeratus 10(1), 12(+); Lotus uliginosus 9(+); Potentilla anserina 3(+). 


\begin{tabular}{|c|c|c|c|c|c|c|c|c|c|c|c|c|c|c|c|c|c|c|c|c|c|}
\hline No. of relevé & 1 & 2 & 3 & 4 & 5 & 6 & 7 & 8 & 9 & 10 & 11 & 12 & 13 & 14 & 15 & 16 & 17 & 18 & 19 & 20 & Con. \\
\hline Myosotis caespitosa & . & 2 & . & 1 & . & . & . & . & . & . & . & + & + & . & . & + & . & . & . & . & II \\
\hline Cirsium arvense & + & . & + & . & + & . & . & . & . & . & . & . & . & . & . & . & . & . & . & . & I \\
\hline Taraxacum sp. & + & . & . & . & . & . & . & . & . & . & . & . & . & + & . & . & . & $\mathrm{r}$ & . & . & I \\
\hline Batrachium sp. juv. & & & & & & & & & & & & & & . & & & & & . & 2 & I \\
\hline \multicolumn{22}{|c|}{ Sporadic: Calamagrostis epigeios $14(+)$; Drepanocladus polycarpos d 9(1), 12(+); Galinsoga parviflora $1(+) ;$ Lemna minor $19(+) ;$ Philonotis arnelli d $9(+)$, } \\
\hline \multicolumn{22}{|c|}{ 10(+); Pohlia nutans d 9(+), 10(+); Polygonum persicaria 3(+), 10(r); Ricciocarpos natans d 19(+); Salix alba 2(+), 4(+); Salix sp. 6(+), 7(r), 8(+), 13(+); } \\
\hline \multicolumn{22}{|c|}{ Salvinia natans $16(+)$; Tanacetum vulgare $14(+)}$. \\
\hline
\end{tabular}

Location: B - Brożek; J - Janiszowice [49]; K - Krzyżowa; P - Poręba Wielka.

This management regime is regulated by humans and does not depend directly on natural factors limiting a water level being favorable for the fern to develop. Nowadays, anthropogenic habitats seem to be one of the most important for the survival of $P$. globulifera. According to correlation of temperature and pillwort continuous range in Central Europe, we define mean annual and January air temperature sufficient for the species to conduct a complete vegetation cycle regularly, as $8.0^{\circ} \mathrm{C}$ and $-3.0^{\circ} \mathrm{C}$ respectively. These isotherms seem to determine the boundary of hypothetical range of the species in Poland; the increase of this area is significant (Fig. 2). Anthropogenic water reservoirs located in this area seem to become potential habitats of $P$. globulifera.

The location in Poręba Wielka is an example of this kind of stand. It is located about $280 \mathrm{~km}$ beyond the eastern boundary of the previous range of $P$. globulifera in Poland. The species was not observed there in the 1990s during a research on Schoenoplectus mucronatus population occurring in the same pond [61]. This new location suggests that the species is able to expand and form stabile populations beyond its historical continuous range. The coincidence of the extending range of thermophilous water ferns with climate warming is confirmed by the expansion of Azolla filiculoides, which was ephemeral in Poland up to the 1980s and began regular wintering at the end of the first decade of the 21st century [62].

As long as sources of spores are present, the spread of this native species to man-made habitats will be a natural process. The main transporting factors of $P$. globulifera propagules are birds [6]. Adhesive gelatinous mass (mucilage) appearing during the release of spores and surrounding hydrated spores can facilitate transportation. Moreover, we observed swans (Cygnus olor) feeding on rhizomes and leaves of Pilularia and Juncus bulbosus and carrying fragments of both species on their necks and feathers [53].

In Poland, $P$. globulifera is protected by law. Specimens are vigorous and not directly destroyed due to their low attractiveness; the main threats are the disappearance of natural habitats and intensive management of potential habitats in anthropogenic fishponds. Pillwort has possibly occurred in more than five known stands during the most recent ten years, but this is difficult to observe due to the ephemeral presence of habitats and the species. This fern requires active protection, mostly in the form of regulation of emersion and immersion periods of fishponds during the year. It is one of species, which exemplifies the important role of man-made habitats for the survival of endangered plants. The high viability of spores, gametophytes and young sporophytes suggests that the species is vigorous, and if conditions are favorable, that further spread will be possible.

Pilularia globulifera sporocarps and living plants were collected in 2008, from a population in Krzyżowa, and the species is currently cultivated in the Botanical Garden of the University of Wrocław. Plants in cultivation are vigorous and regularly produce sporocarps.

\section{Acknowledgments}

The presented research was funded by the Department of Biodiversity and Plant Cover Protection, University of Wrocław.

\section{Authors' contributions}

The following declarations about authors' contributions to the research have been made: wrote the paper: ES; field research: ES, SR, KS, JK, MŚ; phytosociological documentation and analyses: ES, SR; climate analyses and map preparation: MS; preparation of distribution map: MŚ; cariological analysis: AK; cultivation and ex-situ research: RK.

\section{References}

1. Tryon RM, Tryon AF, Hodge WH. Ferns and allied plants: with special reference to tropical America. New York: Springer; 1982.

2. Roux JP. Marsiliaceae-Pteridopsida - first report of the genus Pilularia from continental Africa. Bothalia. 2002;32:82-83.

3. Nagalingum NS, Nowak MD, Pryer KM. Assessing phylogenetic relationships in extant heterosporous ferns (Salviniales), with a focus on Pilularia and Salvinia. Bot J Linn Soc. 2008;157(4):673-685. http://dx.doi. org/10.1111/j.1095-8339.2008.00806.x

4. Crabbe JA. Pilularia L. In: Tutin TG, Burges NA, Charter AO, Edmondson JR, Heywood VH, Moore DM, et al., editors. Flora Europaea. Cambridge: Cambridge University Press; 1993. p. 23. (vol 1).

5. Hultén E, Fries M. Atlas of North European vascular plants: north of the Tropic of Cancer. Königstein: Koeltz; 1986. (vol 1.3).

6. Bennert HW. Die seltenen und gefährdeten Farnpflanzen Deutschlands. Godesberg: Bundesamt für Naturschutz; 1999.

7. Ekrtová E, Ekrt L, Košnar J, Zapomělová E, Čejková A. Míčovka kulkonosná (Pilularia globulifera) znovu objevena v České republice. Zprávy Čes Bot Společ. 2008;43(2):193-208.

8. Żukowski W, Jackowiak B. Pilularia globulifera L. Gałuszka kulecznica. In: 
Kaźmierczakowa R, Zarzycki K, editors. Polska czerwona księga roślin. Paprotniki i rośliny kwiatowe. Cracow: W. Szafer Institute of Botany, Polish Academy of Sciences; 2001. p. 63-64.

9. Dubina DV, Czorna GA. Piliulnicia kulienosna Pilularia globulifera L. In: Diduch JP, editor. Czierwona kniga Ukrainy. Kiev: Globalkonsalting; 2009. p. 33.

10. Bobrov A. Piljunica - Pilularia L. In: Fedorov AA, editor. Flora jevropejskoj czasti SSSR. Leningrad: Nauka; 1974. p. 98. (vol 1).

11. Landsdown R. Pilularia globulifera [Internet]. IUCN red list of threatened species. Version 2011.2. 2011 [cited 2012 Mar 6]; Available from: http:// www.iucnredlist.org

12. Schnittler M, Günther KF. Central European vascular plants requiring priority conservation measures - an analysis from national red lists and distribution maps. Biodivers Conserv. 1999;8(7):891-925. http://dx.doi. org/10.1023/A:1008828704456

13. Moser DM, Gygax A, Baümler B, Wyler N, Palese R. Rote Listen der gefährdeten Tierarten der Schweiz [Internet]. Bern: BUWAL; 1994 [cited 2012 Mar 6]. Available from: http://www.bafu.admin.ch/publikationen/ publikation/00913/index.html?lang=de

14. Korneck D, Schnittler M, Vollmer I. Rote Liste der Farn- und Blütenpflanzen (Pteridophyta et Spermatophyta) Deutschlands. In: Ludwig G, Schnittler M, editors. Schriftenreihe für Vegetationskunde. Bonn: Bayerische Landesamt für Umweltschutz; 1996. p. 21-187. (vol 28).

15. Solstad H, Elven R, Alm T, Alsos IG, Bratli H, Fremstad E, et al. Pteridophyta, Pinophyta, Magnoliophyta [Internet]. In: Kålås JA, Viken Å, Henriksen S, Skjelseth S, editors. The 2010 Norwegian red list for species. Trondheim: Artsdatabanken; 2010 [cited 2012 Mar 6]. p. 155-182. Available from: http://www.artsdatabanken.no/Article.aspx?m=207\&amid=8737

16. Kalliovirta M, Ryttäri T, Håggström CA, Hakalisto S, Kanerva T, Koistinen M, et al. Vascular plants [Internet]. In: Rassi P, Hyvärinen E, Juslén A, Mannerkoski I, editors. The 2010 red list of Finnish species. Helsinki: Ministry of the Environment and Finnish Environment Institute; 2010 [cited 2012 Mar 6]. p. 183-203. Available from: http://www.ymparisto.fi/ default.asp? contentid=371161\&lan=en

17. Gärdenfors U. ArtDatabanken, SLU [Internet]. Rödlistade arter i Sverige 2010. 2010 [cited 2012 Mar 6]; Available from: http://www.slu.se/sv/ centrumbildningar-och-projekt/artdatabanken/om-oss/publikationer/ bocker/2010-rodlistade-arter-i-sverige-2010

18. Weeda EJ, van der Meijden R, Bakker PA. Rode Lijst van de in Nederland verdwenen en bedreigde planten (Pteridophyta en Spermatophyta) over de periode 1.1.1980-1.1.1990. Gorteria. 1990;16(1):2-26.

19. Dostal J. Familie Marsileaceae Kleefarngewachse. In: Kramer KU, editor. Illustrierte Flora von Mitteleuropa. Pteridophyta, Spermatophyta. Berlin: Parey Buchverlag; 1984. p. 285-289. (vol 1.1).

20. Kř́sa B. Marsileaceae - marsilkovité. In: Hejný S, Slavík B, editors. Květena České republiky. Praha: Academia; 1997. p. 282-285. (vol 1).

21. Page $\mathrm{CN}$. The ferns of Britain and Ireland. 2nd ed. Cambridge: Cambridge University Press; 2004.

22. Watson L, Dallwitz MJ. British ferns (Filicopsida). Version: 4th January 2012 [Internet]. Pilularia globulifera L. 2004 [cited 2012 Feb 28]; Available from: http://delta-intkey.com/britfe/www/piluglob.htm

23. Fiek E. Flora von Schlesien preussischen und österreichischen Anteils, enthaltend die wildwachsenden, verwilderten und angebauten Phanerogamen und Gefäss-Cryptogamen. Breslau: J. U. Kern’s Verlag; 1881.

24. Müller W. Flora von Pommern: nach leichtem Bestimmungsverfahren. Stettin: Burmeister; 1898.

25. Müller W. Flora von Pommern. 2nd ed. Stettin: Burmeister; 1904.

26. Müller W. Flora von Pommern. 3rd ed. Stettin: Burmeister; 1911.

27. Schube T. Die Verbreitung der Gefässpflanzen in Schlesien preussischen und österreichischen Anteils. Breslau: Druck von R. Nischowsky; 1903.

28. Kohlhoff KF. Neue Heimatkunde von Pommern. Verlag der Fürstentumer Zeitung A.G.; 1918.

29. Mattfeld J. Bericht über den Frühjahrsauflug am 21 und 22 Mai 1932 nach
Lippehne und Neumark. Verh Bot Ver Prov. 1932-1933;2:216

30. Decker P. Vegetationsverhältnisse in der Niederlausitz. Verh Bot Ver Prov. 1937;77:25-57.

31. Jackowiak B, Żukowski W. Z badań nad rzadkimi i ginącymi gatunkami roślin naczyniowych na Ziemi Lubuskiej. Lubuski Przegląd Przyrodniczy. 1991;2(4):3-21.

32. Żukowski W, Jackowiak B. Pilularia globulifera L. Gałuszka kulecznica. In: Kaźmierczakowa R, Zarzycki K, editors. Polska czerwona księga roślin. Paprotniki i rośliny kwiatowe. Cracow: W. Szafer Institute of Botany, Polish Academy of Sciences; 1993. p. 36-38.

33. Zarzycki K, Szeląg Z. Red list of threatened vascular plants in Poland. In: Zarzycki K, Wojewoda W, Heinrich M, editors. List of threatened plants in Poland. Cracow: W. Szafer Institute of Botany, Polish Academy of Sciences; 1992. p. 87-98.

34. Zarzycki K, Szeląg Z. Red list of the vascular plants in Poland. In: Mirek Z, Zarzycki K, Wojewoda W, Szeląg Z, editors. Red list of plants and fungi in Poland. Cracow: W. Szafer Institute of Botany, Polish Academy of Sciences; 2006. p. 9-20.

35. National Oceanic and Atmospheric Administration [Internet]. Global Historical Climatology Network Monthly. 2011 [cited 2011 Jan 05]; Available from: http://www.ncdc.noaa.gov/ghcnm

36. National Oceanic and Atmospheric Administration [Internet]. Global Surface Summary of Day (GSOD). 2012 [cited 2011 Jan 05]; Available from: http://www.ncdc.noaa.gov/cgi-bin/res40.pl?page=gsod.html

37. Deutscher Wetterdienst [Internet]. 2012 [cited 2012 Mar 18]; Available from: http://www.dwd.de

38. Harris P, Fotheringham AS, Crespo R, Charlton M. The use of geographically weighted regression for spatial prediction: an evaluation of models using simulated data sets. Math Geosci. 2010;42(6):657-680. http://dx.doi. org/10.1007/s11004-010-9284-7

39. Szymanowski M, Kryza M. Local regression models for spatial interpolation of urban heat island - an example from Wrocław, SW Poland. Theor Appl Climatol. 2011;108(1-2):53-71. http://dx.doi.org/10.1007/ s00704-011-0517-6

40. Feulgen R, Rossenbeck H. Mikroskopisch-chemischer Nachweis einer Nucleinsäure vom Typus der Thymonucleinsäure und die darauf beruhende elektive Färbung von Zellkernen in mikroskopischen Präparaten. HoppeSeyler Z Physiol Chem. 1924;135:203-248.

41. Scamoni A. Wstęp do fitosocjologii praktycznej. Warsaw: PWRiL; 1967.

42. Hennekens SM, Schaminée JHJ. TURBOVEG, a comprehensive data base management system for vegetation data. J Veg Sci. 2001;12(4):589-591. http://dx.doi.org/10.2307/3237010

43. Tichý L. JUICE, software for vegetation classification. J Veg Sci. 2002;13(3):451. http://dx.doi.org/10.1658/1100-9233(2002)013[0451:JS FVC]2.0.CO;2

44. Lepš J, Šmilauer P. Multivariate analysis of ecological data using CANOCO [Internet]. Cambridge: Cambridge University Press; 2003. Available from: http://dx.doi.org/10.1017/CBO9780511615146

45. Matuszkiewicz W. Przewodnik do oznaczania zbiorowisk roślinnych Polski. Warsaw: Polish Scientific Publishers PWN; 2001. (Vademecum Geobotanicum; vol 3).

46. Dierssen K. Distribution, ecological amplitude and phytosociological characterization of European bryophytes. Berlin: Cramer in der Gebrüder Borntraeger Verlagsbuchhandlung; 2001. (Bryophytorum Bibliotheca; vol 1).

47. Mirek Z, Piękoś-Mirkowa H, Zając A, Zając M, editors. Flowering plants and pteridophytes of Poland - a checklist. Cracow: W. Szafer Institute of Botany, Polish Academy of Sciences; 2002. (Biodiversity of Poland; vol 1).

48. Zając A. Atlas of distribution of vascular plants in Poland (ATPOL). Taxon. 1978;27(5-6):481-484. http://dx.doi.org/10.2307/1219899

49. Żukowski W, Latowski K, Jackowiak B. Pilularia globulifera L. nad Jeziorem Janoszowice na Ziemi lubuskiej. Fragm Flor Geobot. 1986;31-32:69-76.

50. Żukowski W, Latowski K, Jackowiak B. Pilularia globulifera L. Fragm Flor Geobot. 1988;33:441-446. 
51. Żukowski W. Zagadnienia chorologiczne roślin ginących w Polsce północno-zachodniej. Prace Zakładu Taksonomii Roślin UAM. 1995;3:99-116

52. Holzfuss E. Farnpflanzen Pommerns. Dohrniania. 1933;12:19-33.

53. Szczęśniak E, Szlachetka A. Pillwort Pilularia globulifera L. in Lower Silesia - biology and ecology. In: Szczęśniak E, Gola EM, editors. Club mosses, horsetails and ferns in Poland: resources and protection. Wrocław: Polish Botanical Society; 2008. p. 161-171.

54. Spałek K. Nowe stanowisko gałuszki kulecznicy Pilularia globulifera na Dolnym Śląsku. Chrońmy Przyrodę Ojczystą. 2009;65(6):475-477.

55. Kruk J, Szymańska R. Nowe stanowisko paproci wodnej - gałuszki kulecznicy Pilularia globulifera w Polsce. Chrońmy Przyrodę Ojczystą. 2011;67(1):74-78.

56. Stewart A, Pearman DA, Preston CD. Scarce plants in Britain. Peterborough: JNCC; 1994.

57. Brouwer E, Roelofs JGM. Degraded softwater lakes: possibilities for restoration. Restor Ecol. 2001;9(2):155-166. http://dx.doi. org/10.1046/j.1526-100x.2001.009002155.x

58. Kaplan K, Prolingheuer T. Zur Verbreitung Ökologie und Vergesellschaftung des Pillenfarns (Pilularia globulifera L.) im sudwestlichen Niedersachsen und nordwestlichen Westfahlen. Osnab Natur Mitt. 1989;15:59-72

59. Mäkirinta U. Über das Vorkommen von Pilularia globulifera L. in Finland. Arch Soc Zool Bot Fenn. 1964;18:149-159.

60. Breunig T, Philippi G. Der Pillenfarn (Pilularia globulifera L.) in der mittelbadischen Rheinebene. Carolinea. 1988;46:131-134.

61. Banaś B. Schoenoplectus mucronatus. In: Kaźmierczakowa R, Zarzycki K, editors. Polish red data books of plants. Pteridophytes and flowering plants. Cracow: Polish Academy of Sciences; 2001. p. 469-470.

62. Szczęśniak E, Błachuta J, Krukowski M, Picińska-Fałtynowicz J. Distribution of Azolla filiculoides Lam. (Azollaceae) in Poland. Acta Soc Bot Pol. 2009;78(3):241-246. 